\title{
The range of motion of the back squat exercise affects absolute volume load without changing the rating of perceived exertion
}

\section{$A$ amplitude de movimento no agachamento afeta 0 volume absoluto sem modificar a percepção de esforço}

\author{
Josinaldo Jarbas da Silva ${ }^{1}$ \\ (1D) https://orcid.org/0000-0003-2709-4468 \\ Willy Andrade Gomes ${ }^{1,2}$ \\ (i) https://orcid.org/0000-0003-4223-8917 \\ Silvio Luiz Pecoraro 3 \\ (1) https://orcid.org/0000-0002-3614-479X \\ Enrico Gori Soares ${ }^{3}$ \\ (1) https://orcid.org/0000-0002-8168-9828 \\ Roberto Aparecido Magalhães ${ }^{4}$ \\ (D) https://orcid.org/0000-0002-6595-4230 \\ Gustavo Zorzi Fioravanti ${ }^{3}$ \\ (D) https://orcid.org/ 0000-0001-9323-5180 \\ Rodrigo Baladán ${ }^{3}$ \\ (D) https://orcid.org/0000-0003-4719-6533 \\ Charles Ricardo Lopes ${ }^{3,5}$ \\ (1) https://orcid.org/0000-0003-4278-4969 \\ Paulo Henrique Marchetti ${ }^{6}$ \\ (D) https://orcid.org/0000-0002-2016-936X
}

Abstract - The range of motion (ROM) may affect the external maximal load during back squat (BS) exercise. The correct ROM manipulation can be useful as an exercise load manipulation strategy, changing the volume load during a resistance training session. The aim of this study was to evaluate the acute effects of ROM on relative load, absolute load and the rating of perceived exertion (RPE) during partial and full BS exercise with adjusted loads. Fifteen male individuals (age: $26.5 \pm 4.5$ years; height: $173 \pm 6 \mathrm{~cm}$; body mass: $80.6 \pm 8.8 \mathrm{~kg}$; resistance training experience $5 \pm 3$ years) participated in this study. The experimental procedure was conducted in two sessions. In the first session, brief familiarization and a 10-repetition maximal test (10-RM) was performed for partial (PBS) and full BS exercise (FBS) with 30-min of rest interval. During the second session, all subjects performed 1 set of $10-\mathrm{RM}$ in both conditions (partial and full ROM), and relative load, absolute load, and RPE were evaluated. A paired t-test was used to compare means. The results showed higher values for PBS when compared to FE exercise: relative load (PBS: $1.14 \pm 0.24 \times \mathrm{xW}$ vs. FBS: $0.87 \pm 0.24 \times \mathrm{xW} ; P<0.001$ ), and absolute load (PBS: $925 \pm 249 \mathrm{~kg}$ x FBS: $708 \pm 232 \mathrm{~kg}, P<0.001)$. Similar RPE was observed between conditions (PBS: $8.6 \pm 1.3$ IEP x FBS: $8.5 \pm 1.0$ IEP, $P=0.855$ ). It was concluded that PBS allowed higher relative load and absolute load during 10RM, without effects on RPE.

Key words: Biomechanics; Performance; Resistance training.

Resumo - A amplitude de movimento durante o exercicio agachamento pode afetar a sobrecarga imposta ao sistema neuromuscular. Desta forma, a manipulação da amplitude de movimento pode ser utilizada como estratégia de manipulação da sobrecarga do exercício, alterando o volume absoluto da sessão de treinamento bem como os ajustes agudos do sistema neuromuscular. O objetivo do presente estudo foi avaliar os efeitos agudos da amplitude de movimento na sobrecarga relativa, volume absoluto e na percepção subjetiva de esforço (PSE) durante o exercício agachamento total e parcial com sobrecargas ajustadas. Participaram do estudo 15 homens (idade: $26,5 \pm 4,5$ anos; estatura: $173 \pm 6 \mathrm{~cm}$; massa corporal total: $80,6 \pm 8,8 \mathrm{~kg}$; e tempo de prática no treinamento de força $5 \pm 3$ anos). O experimento foi conduzido em duas sessôes. Na primeira sessão, foi realizada a familiarização, coleta dos dados antropométricos e determinação de 10 repetiçôes máximas (RMs) para o exercicio agachamento parcial $(A P)$ e total $(A T)$. Na segunda sessão, os voluntários realizaram 10-RMs no exercício AP e AT com as sobrecargas ajustadas. Então, os participantes foram orientados a reportar a PSE. Um teste t de student pareado foi utilizado para comparar as médias. Os resultados mostram maior volume relativo ( $A P$ : 1,14 $\pm 0,24 x M C$ vs. AT: 0,87 $\pm 0,24 x M C ; P<0,001)$ e volume absoluto (AP: $925 \pm 249 \mathrm{~kg}$ vs AT: $708 \pm 232 \mathrm{~kg}$, respectivamente, $P<0,001)$ no agachamento parcial quando comparado ao total. A PSE não apresentou diferenças significantes entre amplitudes (AP: 8,6 1,3 vs AT: 8,5 1,0; $P=0,855)$. Conclui-se que a realizaçẫo do AP possibilita a produção de maior volume absoluto e não influencia a PSE

Palavras-chave: Biomecânica; Desempenho; Musculação.
1 Nove de Julho University. Neuromechanics of Strength Training Research Group. Sao Paulo, SP. Brazil.

2 Anhanguera University. Neuromechanics of Strength Training Research Group. Sorocaba, SP. Brazil.

3 Methodist University of Piracicaba. Faculty of Health Sciences. Graduate Program in Human Movement Sciences. Human Performance Research Group. Piracicaba, SP. Brazil.

4 Mogi Guaçu University. Neuromechanics of Strength Training Research Group. Mogi Guaçu, SP. Brazil.

5 Hortolandia Adventist College. Hortolandia, SP. Brazil.

6 California State University-Northridge. Department of Kinesiology. CA. USA.

Received: September 12, 2018 Accepted: March 30, 2019

How to cite this article

Silva JJ, Gomes WA, Pecoraro SL, Soares EG, Magalhães RA, Fioravanti, GZ, Baladan R, Lopes CR, Marchetti PH. The range of motion of the back squat exercise affects absolute volume load without changing the rating of perceived exertion. Rev Bras Cineantropom Desempenho Hum 2020, 22:e58196. D0I: http://dx.doi. org/10.1590/1980-0037.2020v22e58196

Copyright: This work is licensed under a Creative Commons Attribution 4.0 International License. 


\section{INTRODUCTION}

Back squat (BS) exercise has been widely used in resistance training gyms, functional training and rehabilitation clinics for dynamically developing the lower limb muscles; as well as the trunk and upper limbs in a static manner ${ }^{1,2}$. The positioning of the $\mathrm{bar}^{3}$, the distance from the feet ${ }^{4-7}$ and the range of motion $(\mathrm{ROM})^{3,8-11}$ are the main technical strategies that can affect the contribution of muscles involved, and consequently the ability to perform the exercise $e^{8-10,12,13}$. Among these technique variations, the ROM can affect length-tension and torque-angle relationships; therefore, different loads can be lifted when full or partial exercise are performed ${ }^{11,13}$. The ROM affects the time under tension of muscles involved, and may influence the adjustments of loads used and training adaptations ${ }^{14}$.

Caterisano et al..$^{9}$ observed that full squat $\left(0^{\circ}-140^{\circ}\right.$ of knee flexion) presented greater myoelectric activity of the maximum gluteus when compared to partial squat $\left(0^{\circ}-90^{\circ}\right.$ and $0^{\circ}-45^{\circ}$ of knee flexion); however, the study did not consider the effects of ROM on lifting capacity or maximum exercise overload when using body mass percentage as external load. Contreras et al. ${ }^{3}$ compared the mean and peak sEMG during squat exercise under three conditions: partial squat $\left(0^{\circ}-90^{\circ}\right.$ of knee flexion) and full squat with bar positioned in front and back with $\mathrm{ROM}$ of $0^{\circ}-140^{\circ}$ of knee flexion. Thirteen women performed ten repetitions using an estimated load. No difference was observed in mean and peak muscle activity (sEMG) of maximum gluteus and vastus lateralis in both squat exercises. Silva et al. ${ }^{11}$ analyzed the effects of ROM during partial back squat (PBS) and full back squat (FBS) with loads adjusted to 10RM for each ROM. Greater myoelectric activity was observed in the vastus lateralis, vastus medialis, maximum gluteus, long head of the biceps femoris, soleus and erector of the spine in PBS when compared to FBS.

Based on the concept that ROM affects load imposed on exercise, the rating of perceived exertion (RPE) could also be influenced by the physical effort performed. Tiggemann et al. ${ }^{15}$ and Day et al. ${ }^{16}$ demonstrate that RPE is affected by load variations and muscle activity levels. Thus, the aim of the present study was to evaluate the acute effects of the range of motion on relative load, absolute load and rating of perceived exertion during PBS and FBS with adjusted loads in recreationally-trained individuals. The hypothesis is based on the previous scientific concept that both maximum conditions will have no difference in the RPE. However, the absolute load and relative strength will be greater for PBS.

\section{METHOD}

The sample consisted of 15 healthy men (age: $26.5 \pm 4.5$ years; height: $173 \pm 6 \mathrm{~cm}$; total body mass: $80.6 \pm 8.8 \mathrm{~kg}$; time of practice in resistance training: $5 \pm 2.9$ years). The number of participants was determined using load data obtained from a pilot study that was previously carried out 
with individuals who have the same characteristics as those participating in the present study, based on a 5\% significance and test power of $80 \%{ }^{17}$. All participants were recreationally-trained in resistance training with previous experience in PBS exercises for at least one year with frequency of at least three times a week using intensities between 6 and 12-RMs. None of participants presented any osteomioarticular involvement (injury / surgery) in the lower limb, trunk and / or shoulder. All participants were informed of the experimental procedures, read and signed the Informed Consent Form, approved by the University's Research Ethics Committee (Protocol No. 68/2016).

Participants were instructed to abstain from any physical activity for the lower limbs in the 72 hours prior to the two visits to the laboratory. On the first visit, personal data were collected through oral questioning (name, age, time of practice in resistance training and $\mathrm{BS}$ exercise and preference in kicking a ball to determine foot dominance) ${ }^{18}$. Anthropometric data (total body mass and height) were measured. Then, participants performed a brief warm-up on cycle ergometer for five minutes at 70 revolutions per minute without external resistance. After warming up, participants were tested for maximum load lifted in 10 maximum repetitions (10-RM) in the free BS exercise in two specific amplitudes [partial (PBS): from $0^{\circ}$ to $90^{\circ}$; and full (FBS): from $0^{\circ}$ to $140^{\circ}$ of knee flexion]. A mark was made on the floor to ensure that the participants' feet remained in the same position during both conditions. The distance between feet was self-selected to ensure closer approach to the practice. During tests, participants were instructed to report the effort performed in each attempt to be familiarized with the scale adapted from Foster et al. ${ }^{19}$, regarding the rated perceived exertion (RPE). In the second session, participants performed a random series of $10 \mathrm{RMs}$ of squat exercise for each range of motion (partial and full). Immediately after the end of sets, participants were instructed to report their rating of perceived exertion (RPE). During all conditions, participants were accompanied and observed by a strength training specialist responsible for the safety and maintenance of the back squat execution technique in the different experimental conditions.

\section{Assessments}

Maximum Repetitions Test (10-RMs): 10-RMs test was performed for the free BS exercise in the different experimental conditions (PBS and FBS). Feet position was predetermined in the warm-up exercise and was the same during all experimental conditions. The test consisted of performing up to five attempts with increasing overloads and with five-minute interval between attempts. The initial load was estimated by participants based on their training experience ${ }^{20,21}$. Movements were performed in a self-selected cadence with 30-min interval between the two experimental conditions in a randomized way. The ROM was controlled by an electrogoniometer aligned to the knee joint center of the dominant lower limb (PBS: $0^{\circ}-90^{\circ}$ of knee flexion and FBS: $0^{\circ}-140^{\circ}$ of knee flexion. Participants returned 
to their initial position through the full knee and hip extension. Any interruption in the execution of the movement between ascending and descending phases was not allowed, and only repetitions with correct execution of exercises were valid. To minimize errors in tests, the following strategies were adopted: (I) participants received information about the appropriate exercise technique before tests (II) the execution of the exercise technique was monitored and corrected when necessary (III) participants were verbally encouraged during tests and (IV) participants performed the movements until concentric failure.

Electrogoniometry: Electrogoniometer (EMG System do Brasil, São José dos Campos, Brazil) was attached close to the knee joint center of the dominant limb of each participant to define the knee flexion angle and the ascending and descending phases of the movement in each repetition performed. Data acquisition was carried out at frequency of $2000 \mathrm{~Hz}$.

Rating of Perceived Exertion (RPE): RPE was verified through the scale of Foster et al. ${ }^{19}$. The appraiser instructed participants to choose a descriptor and then a number from 0 to 10 , which was also provided in decimals (for example: 7.5). The maximum value (10) was compared to the greatest physical effort experienced by the participant and the minimum value was the condition of absolute rest (0). Immediately after PBS and FBS, each participant was asked: "How was your training?". Through $\mathrm{RPE}$, the participant indicated a value from zero to ten, where zero means extremely easy and 10 means extremely difficult. Thus, RPE represented a global value of perceived effort intensity for each experimental condition.

\section{Data analysis}

The loadoad lifted during the 10-RM test for PBS and FBS was normalized by the total body mass of each participant. Therefore, the ratio between weight of the bar and the total body mass of participants was calculated and expressed in multiples of total body mass (xBM). The absolute load (AL) was calculated using the product of maximum repetitions (RMs) by the lifted load (kg).

\section{Statistical analysis}

The normality and homogeneity of variances were verified using the ShapiroWilk and Levene test, respectively. All data were reported using mean and standard deviation (SD) of the mean. Paired student t-test was used to verify differences in the overload used in 10-RMs, in the absolute load and in the rated perceived exertion. The effect size calculation (d) was performed using Cohen's formula and results were based on the following criteria: $<0.35$ trivial effect; $0.35-0.80$ small effect; $0.80-1.50$ moderate effect; and $>1.5$ great effect, for recreationally-trained individuals according to Rhea ${ }^{22}$. Significance $(\alpha)$ of $5 \%$ was used for all statistical tests, using SPSS software version 21.0.

\section{RESULTS}

Participants had higher relative overload for 10RM in PBS when compared 
to FBS (PBS: $1.14 \pm 0.24 \times \mathrm{xBM}$ vs. FBS: $0.87 \pm 0.24 \mathrm{xBM} ; P<0.001, d=$ 1.12 [moderate effect], $\Delta \%=23.68$ ). Higher absolute load was found in PBS when compared to FBS (PBS: $925 \pm 249 \mathrm{~kg}$ and FBS: $708 \pm 232 \mathrm{~kg}$, $P<0.001, d=0.9$ [moderate effect], $\Delta \%=23.41$ ), (Figure $1 \mathrm{~A}$ ). However, no significant difference was observed for RPE in both squat exercises (PBS: $8.6 \pm 1.3$ AU vs. FBS: $8.5 \pm 0.9$ AU; $P=0.855, d=0,05$ [trivial effect], $\Delta \%=0.8)$, (Figure $1 \mathrm{~B}$ ).
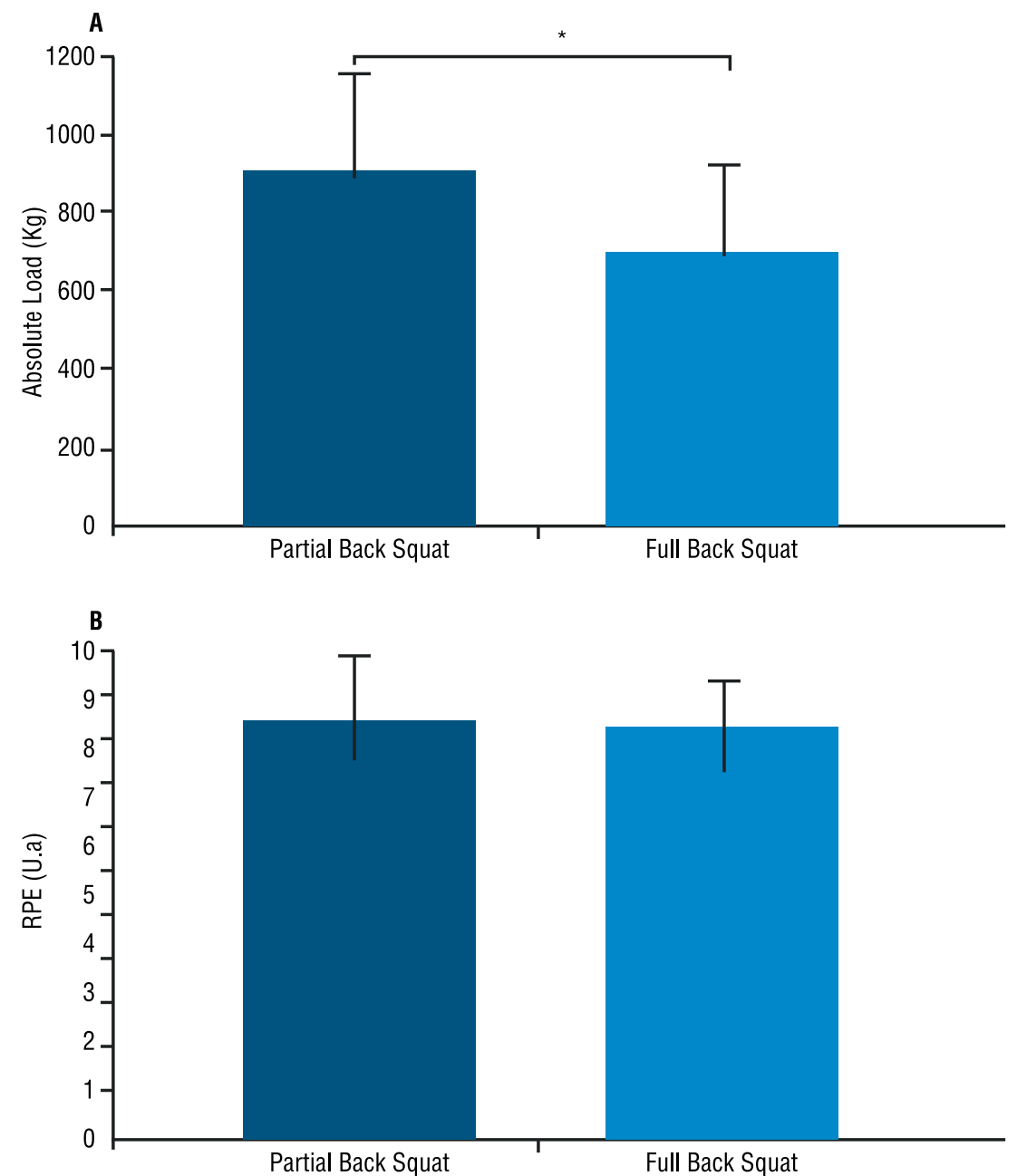

Figure 1. Mean and standard deviation of absolute load (a) and rating of perceived exertion (b) for partial back squat and full back squat. ${ }^{*}$ Significant difference, $P<0.05$.

\section{DISCUSSION}

The aim of the present study was to evaluate the acute effects of the range of motion on relative load, absolute load and on the rating of perceived exertion during full (FBS) and partial (PBS) back squat exercise with adjusted loads in recreationally-trained individuals. Higher relative load (23.68\%) and absolute load (23.41\%) was observed in PBS when compared to FBS. However, there were no significant differences in RPE after performing PBS and FBS. Thus, the results of the present study corroborate the initial hypothesis that states that the difference in the lifting capacity does not 
affect RPE since loads were adjusted to the RM of each participant.

The greater load lifted in the partial range is mainly due to mechanical (length-tension relationship and "sticking point") and neurophysiological (facilitating action of muscle spindles) differences related to the ROM during exercise. From the mechanical point of view, the back squat exercise has an ascending characteristic in the strength production, which means that as the concentric phase progresses, greater loads are possible to be lifted ${ }^{23,24}$. Thus, the greatest load that can be lifted in the exercise is determined by the point of least strength, which is known as the "sticking point" and is defined by the point of greatest mechanical disadvantage in the entire ROM of the exercise ( $90^{\circ}$ of knee flexion for BS); after this point, lifting can be completed without major difficulties ${ }^{25}$. The RPE scale is a method used in training sciences mainly to measure the perceived exertion intensity in a given exercise $\mathrm{e}^{15,16,19}$. In the present study, there was no significant difference in RPE for BS exercise at different ROMs (PBS and FBS), with adjusted loads (10-RMs), corroborating Tiggemann et al. ${ }^{15}$, who verified similar responses for RPE when maximum efforts were performed (RMs). However, RPE is sensitive to load variations used in exercises $^{16,19,26}$. Thus, it is possible that the greater ROM performed in FBS may have affected RPE due to the change in time under tension of the muscle-tendon unit ${ }^{15}$, which in turn, may have compensated for the lower overload used. Additionally, it is possible that mechanoreceptors such as muscle spindles, Golgi tendon organs and afferent articular and cutaneous receptors may also have contributed to reported $\mathrm{RPEs}^{27}$; however, such influences were not analyzed in the present study. The results of the present study may be subject to limitations as it includes only healthy, recreationally-trained male participants, which limits the applicability of our findings to other populations. However, the selected design sought to resemble the resistance training practice using 10RMs and cadence self-selected by participants. Thus, the present study has great practical applicability for physical education professionals and strength training practitioners, who can use OBS exercise in order to increase strength production capacity without changing RPE.

\section{CONCLUSION}

It could be concluded that the range of motion of the back squat exercise affects practitioner's weight lifting capacity and RPE when loads used are maximum (RMs).

\section{COMPLIANCE WITH ETHICAL STANDARDS}

\section{Funding}

This research did not receive any specific grant from funding agencies in the public, commercial, or not-for-profit sectors. This study was funded by the authors. 


\section{Ethical approval}

Ethical approval was obtained from the local Human Research Ethics Committee-Methodist University of Piracicaba, protocol (no.\#68/2016X) was written in accordance with standards set by the Declaration of Helsinki.

\section{Conflict of interest statement}

The authors have no conflict of interests to declare.

\section{Author Contributions}

Conceived and designed the experiments: JJS, WAG, and PHM. Performed the experiments: JJS, WAG, SLP, and PHM. Analyzed data: JJS, PHM. Contributed with materials/analysis tools: WAG, SLP, RAM, EGS, GZF, RB and CRL. Wrote the paper: JJS, WAG and PHM.

\section{REFERENCES}

1. Marchetti PH, Gomes WA, Luz Junior DA, Giampaoli B, Amorim MA, Bastos HL, et al. Aspectos neuromecânicos do exercício agachamento. Rev Cent Pesqui Av Qual Vida 2013;5(2): 1-16.

2. Marchetti PH, Calheiros Neto RB, Charro MA. Biomecânica Aplicada: Uma abordagem para o treinamento de força. São Paulo: Phorte; 2019.

3. Contreras B, Vigotsky AD, Schoenfeld BJ, Beardsley C, Cronin J. A comparison of gluteus maximus, biceps femoris, and vastus lateralis EMG amplitude in the parallel, full, and front squat variations in resistance trained females. J Appl Biomech 2016;32(1):16-22.

4. Paoli A, Marcolin G, Petrone N. The effect of stance width on the electromyographical activity of eight superficial thigh muscles during back squat with different bar loads. J Strength Cond Res 2009;23(1):246-50.

5. Escamilla RF, Fleisig GS, Lowry TM, Barretine SW, Andrews JR. A threedimensional biomechanical analysis of the squat during varying stance widths. Med Sci Sports Exerc 2001;33(6):984-98.

6. Escamilla RF, Fleisig GS, Zheng N, Lander JE, Barrentine SW, Andrews JR, et al. Effects of technique variations on knee biomechanics during the squat and leg press. Med Sci Sports Exerc 2001:1552-6.

7. Ninos JC, Irrgang JJ, Burdett R, Weiss JR. Electromyographic analysis of the squat performed in self-selected lower extremity neutral rotation and 30 degrees of lower extremity turn-out from the self-selected neutral position. J Orthop Sports Phys Ther 1997;25:307-15.

8. Bloomquist K, Langberg H, Karlsen S, Madsgaard S, Boesen M, Raastad T. Effect of range of motion in heavy load squatting on muscle and tendon adaptations. Eur J Appl Physiol 2013;113:2133-42.

9. Caterisano A, Moss RF, Pellinger TK, Woodruff K, Lewis VC, Booth W. The effect of back squat depht on the EMG activity of 4 superficial hip and thigh muscles. J Strength Cond Res 2002;16:428-32.

10. Marchetti PH, Silva JJ, Schoenfeld BJ, Nardi PSM, Pecoraro SL, Greve JMDA, et al. Muscle activation differs between three different knee joint-angle positions during a maximal isometric back squat exercise. J Sports Med 2016;2016:1-6.

11. Silva JJ, Schoenfeld BJ, Marchetti PN, Pecoraro SL, Greve JMDA, Marchetti $\mathrm{PH}$. Muscle activation differs between partial and full back squat exercise with external load equated. J Strength Cond Res 2017;31(6):1688-93.

12. Ebben WP, Leigh DH. The role of the back squat as a hamstring training stimulus. J Strength Cond Res 2000;22(5):15-7. 
13. Sugisaki N, Kurokawa S, Okada J, Kaneshia H. Difference in the recruitment of hip and knee muscles between back squat and plyometric squat jump. Plos One 2014;9(6):1-9.

14. Tran QT, Docherty D, Behm D. The effects of varying time under tension and volume load on acute neuromuscular responses. Eur J Appl Physiol 2006;98(4):402-10.

15. Tiggemann CL, Pinto RS, Kruel LFM. A percepção de esforço no treinamento de força. Rev Bras Med Esporte 2010;16(4):301-9.

16. Day ML, McGuigan MR, Brice G, Foster C. Monitoring exercise intensity during resistance training using the session RPE scale. J Strength Cond Res 2004;18(2):353-8.

17. Eng J. Sample Size Estimation: How many individuals should be studied? Radiol 2003;227(2):309-13.

18. Maulder P, Cronin J. Horizontal and vertical jump assessment: reliability, symmetry, discriminative and predictive ability. Phys Ther Sport 2005;6(2):74-82.

19. Foster C, Florhaug JA, Franklin J, Gottschall L, Hrovatin LA, Parker S, et al. A new approach to monitoring exercise training. J Strength Cond Res 2001;15(1):109-15.

20. Bentes CM, Simão R, Bunker T, Rhea MR, Miranda H, Gomes TM, et al. Acute Effects of Dropsets Among Different Resistance Training Methods in Upper Body Performance. J Hum Kinet 2012;34:105-11.

21. Baechle TR, Earle RW. Fundamentos do treinamento de força e do condicionamento. 3 ed. São Paulo: Manole; 2010.

22. Rhea MR. Determining the magnitude of treatment effects in strength training research through the use of the effect size. J Strength Cond Res 2004;18(4):918-20.

23. Zatsiorsky VM, Kraemer WJ. Ciência e prática do treinamento de força. São Paulo: Phorte; 2008.

24. Robertson DGE, Wilson JJ, St. Pierre TAS. Lower extremity muscle functions during full squats. J Appl Biomech 2008;24:333-9.

25. Kompf J, Arandjelovic O. Understanding and overcoming the sticking point in resistance exercise. Sports Med 2016;46(6):751-62.

26. Sweet TW, Foster C, McGuigan MR, Brice G. Quantitation of resistance training using the session rating of perceived exertion method. J Strength Cond Res 2004;18(4):796-802.

27. Watt B, Grove R. Perceived exertion. Antecedents and applications. Sports Med 1993;15(4):225-41.

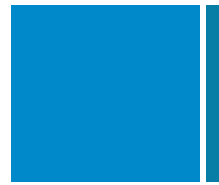

Corresponding author

Paulo H. Marchetti

California State University-Northridge, Department of Kinesiology.

18111 Nordhoff Street, Northridge, CA, 91330, USA.

Email:dr.pmarchetti@gmail.com 